\title{
THE NON-SODIUM NICKEL HYDROXYCARBONATE FOR NANOSIZED CATALYSTS
}

\author{
Olena Korchuganova ${ }^{1}$, Emiliia Tantsiura ${ }^{1,}{ }^{凶}$, Marina Ozheredova $^{1}$, Iryna Afonina ${ }^{1}$
}

https://doi.org/10.23939/chcht14.01.007

\begin{abstract}
The samples of non-sodium nickel hydroxycarbonate for nanosized catalysts have been obtained and investigated. The ratio of crystalline water, the amount of nickel hydroxide and carbonate has been calculated. By the X-ray analysis of obtained nickel oxide the crystallite size of $12-13 \mathrm{~nm}$ has been determined. The samples of catalysts provided a high specific surface.
\end{abstract}

Keywords: nickel hydroxycarbonate, precipitation, precipitant, nickel oxide, catalysts.

\section{Introduction}

Nanosized nickel oxide has found its use in modern industry foremost as component of catalysts, adsorbents, and nanocomposites. It can be applied in optical, electronic and super-paramagnetic equipment and devices such as gas sensors, electrodes for batteries, as well as the sensitizing dye of solar cells, solid oxide fuel cells, etc. [1-5]. Each of the areas of using sets particular requirements to the properties of nickel oxide. Moreover, modern catalysts industry requires superfine nickel oxide [6] with a high specific surface area [7], without any admixture of alkali metal that can decrease the surface area and reduce the catalytic activity [8]. Nickel oxide catalysts are widely available due to their unique ratio of price to catalytic property. Hence, they can be applied in new technologies [9] .

Nickel oxide is mostly obtained by thermal decomposition of nickel hydroxycarbonate, obtained by precipitating from aqueous solutions of nickel salts [1012]. Nickel hydroxycarbonate can also be formed in the process of disposal of liquid waste and wastewater [13]. The properties of precipitates, their chemical and phase composition, and crystal structure are formed during the precipitation process, depending on the method, precipitant type, and process conditions. The properties of the oxides depend on their precursor properties. It takes some precipitants of the chemical composition without

\footnotetext{
${ }^{1}$ Volodymyr Dahl East Ukrainian National University,

59a, Central'nyj Ave., 93400 Severodonetsk, Ukraine

emiliia.tantsiura@gmail.com

(c) Korchuganova O., Tantsiura E., Ozheredova M., Afonina I., 2020
}

any sodium to obtain low-sodium nickel hydroxycarbonate. Ammonium carbonate and urea are used as non-sodium precipitants. These processes require different conditions, which can lead to different composition and properties of the nickel hydroxycarbonate obtained.

Nickel hydroxycarbonate is a salt of unstable composition that contains different amount of crystal water and different proportion of nickel carbonate/nickel hydroxide. Commonly salt producers provide the general formula $x \mathrm{NiCO}_{3} \cdot y \mathrm{Ni}(\mathrm{OH})_{2} \cdot z \mathrm{H}_{2} \mathrm{O}$ [5]. They indicate the content of nickel as the main component of raw materials. It should be stated that in the process of thermal decomposition carbonate and hydroxide ions pass into the gas phase and become a ballast that must be utilized. Determination of the $x: y: z$ ratio is very important to elaborate the processes of the preparation of catalysts and sorbents, to provide the specified content of the nickel in the completed product, and to determine the volume of gaseous products of the process, its parameters and methods of waste disposal.

The article presents the results of the studies of chemical and phase composition of precipitates obtained by precipitation of ammonium carbonates (carbonic ammonium salts) and urea, and comparison with the chemical and phase composition of precipitates obtained by means of a common sodium carbonate precipitant prepared from solutions of nickel chloride and nickel sulfate at the temperature of $298 \mathrm{~K}$.

\section{Experimental}

\subsection{Materials and Methods}

The following chemicals were taken to get samples of non-sodium nickel hydroxycarbonate: nickel nitrate $\mathrm{Ni}\left(\mathrm{NO}_{3}\right)_{2} \cdot 6 \mathrm{H}_{2} \mathrm{O}$, nickel sulfate $\mathrm{NiSO}_{4} \cdot 7 \mathrm{H}_{2} \mathrm{O}$, nickel chloride $\mathrm{NiCl}_{2} \cdot 6 \mathrm{H}_{2} \mathrm{O}$ (Ural Chemical Reagent Plant, Russia), sodium carbonate (Donetsk Chemical Reagent Plant, Ukraine), and ammonium carbonates (carbon ammonium salts, PJSC Severodonetsk AZOT Association). They are semi-products of urea and a mixture of ammonium salts, specifically, ammonium carbonate 
(75-88\%), ammonium bicarbonate (6-12\%), and urea. One should note here that the carbon ammonium salts are cheaper than the urea and will significantly reduce the cost of the nickel hydroxycarbonate produced.

Concentrated solutions of nickel nitrate which are common raw materials in the production of catalysts were used to obtain samples of non-sodium precipitates. Keeping the temperature conditions of the process is a requirement for ensuring a sufficient speed of precipitation. Therefore, the precipitation of nickel hydroxycarbonate by means of carbon ammonium salts was carried out at the temperature of $298 \mathrm{~K}$, and the precipitation by urea was carried out at the temperature above $363 \mathrm{~K}$, since reaction (2) run at a sufficient speed only under such temperature conditions. Precipitation solutions (carbon ammonium salt and sodium carbonate solutions) were added dropwise to minimize local supersaturation. There was no need in urea dosing because precipitation is the result of the gradual formation of precipitates in the solution - ammonia and carbon(IV) oxide by reaction (2) and the subsequent course of the formation reaction of nickel hydroxycarbonate (3). For comparison, chemical properties of precipitates obtained by sodium carbonate from nickel sulfate and nickel chloride at the temperature of $298 \mathrm{~K}$ were investigated.

After precipitation, the precipitates were filtered off, washed with distilled water and dried. The amount of the water and the degree of its heating required to wash the precipitates were determined experimentally by the negative reaction to the presence of residual anions of nickel salts. The dried precipitates were examined by DTA and X-ray diffraction.

The chemistry of precipitation processes is characterized as follows:

i) We use the reaction (1) to describe the process for obtaining samples 1-4:

$$
\begin{gathered}
3 \mathrm{Ni}\left(\mathrm{NO}_{3}\right)_{2}+3\left(\mathrm{NH}_{4}\right)_{2} \mathrm{CO}_{3}+6 \mathrm{H}_{2} \mathrm{O} \leftrightarrow \\
\leftrightarrow \mathrm{NiCO}_{3} \cdot 2 \mathrm{Ni}(\mathrm{OH})_{2} \cdot 4 \mathrm{H}_{2} \mathrm{O}+6 \mathrm{NH}_{4} \mathrm{NO}_{3}+2 \mathrm{CO}_{2} \uparrow
\end{gathered}
$$

The precipitation was carried out under constant stirring by means of the mechanical device. Carbon ammonium salt solution was added into nickel nitrate solution in a dropping mode to achieve $\mathrm{pH}=7 \pm 0.1$. It took us $30 \mathrm{~min}$ to precipitate samples 1 and 3; however, $60 \mathrm{~min}$ were needed for samples 2 and 4 . Precipitation temperature was $298 \pm 2 \mathrm{~K}$. The additional alkalization by ammonia was used to obtain samples 3 and 4 .

ii) The nickel nitrate solutions of different initial concentration (Table 1) and urea were used to obtain samples 5-7.

The precipitates were obtained in the following way: urea in the molar ratio of $\mathrm{Ni}\left(\mathrm{NO}_{3}\right)_{2}: \mathrm{CO}\left(\mathrm{NH}_{2}\right)_{2}=1: 3$ was added to a pre-prepared solution of nickel nitrate with fixed concentration. The process time was $90-120 \mathrm{~min}$, $\mathrm{pH}$ value increased to $7-7.25$ due to the urea hydrolysis:

$$
\begin{aligned}
& \mathrm{CO}\left(\mathrm{NH}_{2}\right)_{2}+2 \mathrm{H}_{2} \mathrm{O} \leftrightarrow 2 \mathrm{NH}_{4} \mathrm{OH}+\mathrm{CO}_{2} \\
& \text { The precipitation is described by Eq. (3): } \\
& 3 \mathrm{Ni}\left(\mathrm{NO}_{3}\right)_{2}+3 \mathrm{CO}\left(\mathrm{NH}_{2}\right)_{2}+12 \mathrm{H}_{2} \mathrm{O} \leftrightarrow \\
& \leftrightarrow \mathrm{NiCO}_{3} \cdot 2 \mathrm{Ni}(\mathrm{OH})_{2} \cdot 4 \mathrm{H}_{2} \mathrm{O}+6 \mathrm{NH}_{4} \mathrm{NO}_{3}+2 \mathrm{CO}_{2}
\end{aligned}
$$

iii) The precipitation of samples 8-11 has been carried out in the following way: the sodium carbonate solution saturated at the temperature of $298 \pm 2 \mathrm{~K}$ to $\mathrm{pH}=9-9.5$ was dosed in glasses containing $100 \mathrm{~cm}^{3}$ of stock solution (nickel sulfate was prepared using $\mathrm{NiSO}_{4} \cdot 7 \mathrm{H}_{2} \mathrm{O}$ or nickel chloride, which were prepared using $\mathrm{NiCl}_{2} \cdot 6 \mathrm{H}_{2} \mathrm{O}$ ). The precipitation temperature was $298 \pm 2 \mathrm{~K}$; stirring was performed by magnetic stirrer. The processes were described by Eqs. (3) and (4):

$$
\begin{gathered}
3 \mathrm{NiSO}_{4}+3 \mathrm{Na}_{2} \mathrm{CO}_{3}+6 \mathrm{H}_{2} \mathrm{O}= \\
=\mathrm{NiCO}_{3} \cdot 2 \mathrm{Ni}(\mathrm{OH})_{2} \cdot 4 \mathrm{H}_{2} \mathrm{O}+3 \mathrm{Na}_{2} \mathrm{SO}_{4}+2 \mathrm{CO}_{2} \\
3 \mathrm{NiCl}_{2}+3 \mathrm{Na}_{2} \mathrm{CO}_{3}+6 \mathrm{H}_{2} \mathrm{O}= \\
=\mathrm{NiCO}_{3} \cdot 2 \mathrm{Ni}(\mathrm{OH})_{2} \cdot 4 \mathrm{H}_{2} \mathrm{O}+6 \mathrm{NaCl}+2 \mathrm{CO}_{2}
\end{gathered}
$$

The precipitation time was $60 \mathrm{~min}$ for low concentrated solutions and $90 \mathrm{~min}$ for the concentrated ones. Precipitant amount was 1.1-1.2 of the theoretical one.

DTA and X-ray studies of nickel hydroxycarbonate (Donetsk Chemical Reagents Plant, Ukraine) were conducted. X-ray analysis was performed on diffractometer DRON-7 in $\mathrm{Cu} \mathrm{K}-\alpha$ radiation using a software system PDWin. The size of nickel oxide crystallites was determined by the full width at halfmaximum (FWHM). DTA was carried out on derivatograph Q-1500 by MOM company in the aerial environment by varying range of temperatures from 293 to $1223 \mathrm{~K}$; the sample weight was $200 \mathrm{mg}$, the heating rate was 10 degrees $/ \mathrm{min}$.

The catalyst samples were prepared for further investigations from the specimens with the maximum $(>50 \%)$ amount of nickel.

Catalysts were prepared using two kinds of active alumina $\left(\gamma-\mathrm{A}_{2} \mathrm{O}_{3}\right)$ : aluminum nitrate (solution was prepared from $\mathrm{Al}\left(\mathrm{NO}_{3}\right)_{3} \cdot 9 \mathrm{H}_{2} \mathrm{O}$ in the laboratory) and urea, as well as from commercial active alumina using nitrate aluminum and ammonia. Both of the obtained precursors of active alumina have been calcined at the temperature of $723 \mathrm{~K}$ for $2 \mathrm{~h}$.

The samples were prepared in the following way: $100 \mathrm{~g}$ of active alumina and $100 \mathrm{~g}$ of nickel hydroxycarbonate were stirred in a glass for $10 \mathrm{~min}$; then $200 \mathrm{ml}$ of aqueous ammonia (25\%) were added. The mass has been stirred for $10 \mathrm{~min}$. The resulting mass was heated to $333-353 \mathrm{~K}$ and stirred for extra $10 \mathrm{~min}$. After the stirring, the mass was dried within the temperature range of 373-393 K. Then, desiccated mass has been calcined at the temperature of $693 \mathrm{~K}$ for $3 \mathrm{~h} .5 \%$ of the graphite as the binding agent was added to the cooled calcined mass. After stirring the catalyst granules were tableted from the mass. 
A specific surface area of the prepared samples was measured via thermal desorption of argon by BET method.

\subsection{Theory and Calculations}

The number of precipitates of nickel hydroxides and carbonates which can be identified by X-ray diffraction data is large enough:

$\mathrm{Ni}(\mathrm{OH})_{2}, \quad 3 \mathrm{Ni}(\mathrm{OH})_{2} \cdot 2 \mathrm{H}_{2} \mathrm{O}, \quad \mathrm{Ni}(\mathrm{OH})_{2} \cdot 0,75 \mathrm{H}_{2} \mathrm{O}$, $4 \mathrm{Ni}(\mathrm{OH})_{2} \cdot \mathrm{NiOOH}, \quad \mathrm{NiOOH}, \quad \mathrm{Ni}_{5} \mathrm{O}(\mathrm{OH})_{9}, \quad \mathrm{NiCO}_{3}$, $\mathrm{NiCO}_{3} \cdot 6 \mathrm{H}_{2} \mathrm{O}, \quad \mathrm{Ni}_{2} \mathrm{CO}_{3}(\mathrm{OH})_{2} \cdot \mathrm{H}_{2} \mathrm{O}, \quad \mathrm{Ni}_{2} \mathrm{CO}_{3}(\mathrm{OH})_{2} \cdot 4 \mathrm{H}_{2} \mathrm{O}$, $\mathrm{Ni}_{3} \mathrm{CO}_{3}(\mathrm{OH})_{4} \cdot 4 \mathrm{H}_{2} \mathrm{O}, \mathrm{Ni}_{5}\left(\mathrm{CO}_{3}\right)_{4}(\mathrm{OH})_{2} \cdot 4,5 \mathrm{H}_{2} \mathrm{O}, \mathrm{Ni}\left(\mathrm{HCO}_{3}\right)_{2}$, and $\mathrm{NiCO}_{3}\left(\mathrm{H}_{2} \mathrm{O}\right)_{4} \cdot 1,5 \mathrm{H}_{2} \mathrm{O}$.

Besides the aforementioned basic carbonates and hydroxides, the precipitates obtained from solutions can contain basic salts of nickel [15] formed by the participation of precursor salt anion.

Experimental investigations of the thermal decomposition mechanism of metal hydroxycarbonates were difficult because of superimposing of the temperature ranges of the processes of dehydration, dehydroxylation, and decarbonization. Consequently, the authors [16] have determined general laws of reactions coherence by jointing application of DTA and gasvolumetric methods; they have proposed the following scheme of thermal decomposition. Conventionally the process of the thermal decomposition can be divided into the following stages:

- the first stage is the removal of a moisture and crystallization water within the temperature range of $323-423 \mathrm{~K}$

$\mathrm{NiCO}_{3} \cdot \mathrm{Ni}(\mathrm{OH})_{2} \cdot n \mathrm{H}_{2} \mathrm{O} \stackrel{t}{\longrightarrow} \mathrm{NiCO}_{3} \cdot \mathrm{Ni}\left(\mathrm{OH}_{2}\right)+n \mathrm{H}_{2} \mathrm{O}$

- the second stage is the decomposition of hydroxide in the crystal grating of the basic carbonate with the removal of a hydroxide water and the formation of oxide and carbonate within the temperature range of $323-423 \mathrm{~K}$

$\mathrm{NiCO}_{3} \cdot \mathrm{Ni}(\mathrm{OH})_{2} \stackrel{t}{\longrightarrow} \mathrm{NiCO}_{3}+\mathrm{NiO}+\mathrm{H}_{2} \mathrm{O}$

- the third stage is the decomposition of carbonates formed by the destruction of the crystal grating of the basic carbonate within the temperature range of $523-773 \mathrm{~K}$

$$
\mathrm{NiCO}_{3} \stackrel{t}{\longrightarrow} \mathrm{NiO}+\mathrm{CO}_{2}
$$

\section{Results and Discussion}

Fig. 1 shows an external view of precipitate $\mathrm{X}$-ray powder diffraction patterns; characteristic peaks denote existing separate phases. Table 1 contains data on precipitates containing phase identification.

Fig. 1a shows an external view of samples obtained by precipitation with ammonium carbonate (sample 1) and urea (sample 5), as well as an X-ray of industrial sample of nickel hydroxycarbonate (sample 12). Fig. 1b shows an $\mathrm{X}$-ray of samples obtained from solutions of nickel sulfate (sample 8) and nickel chloride (sample 10).

Therefore, a mixture of different phases in the experimental samples of nickel precipitates obtained under various conditions by using qualitative phase analysis was identified.
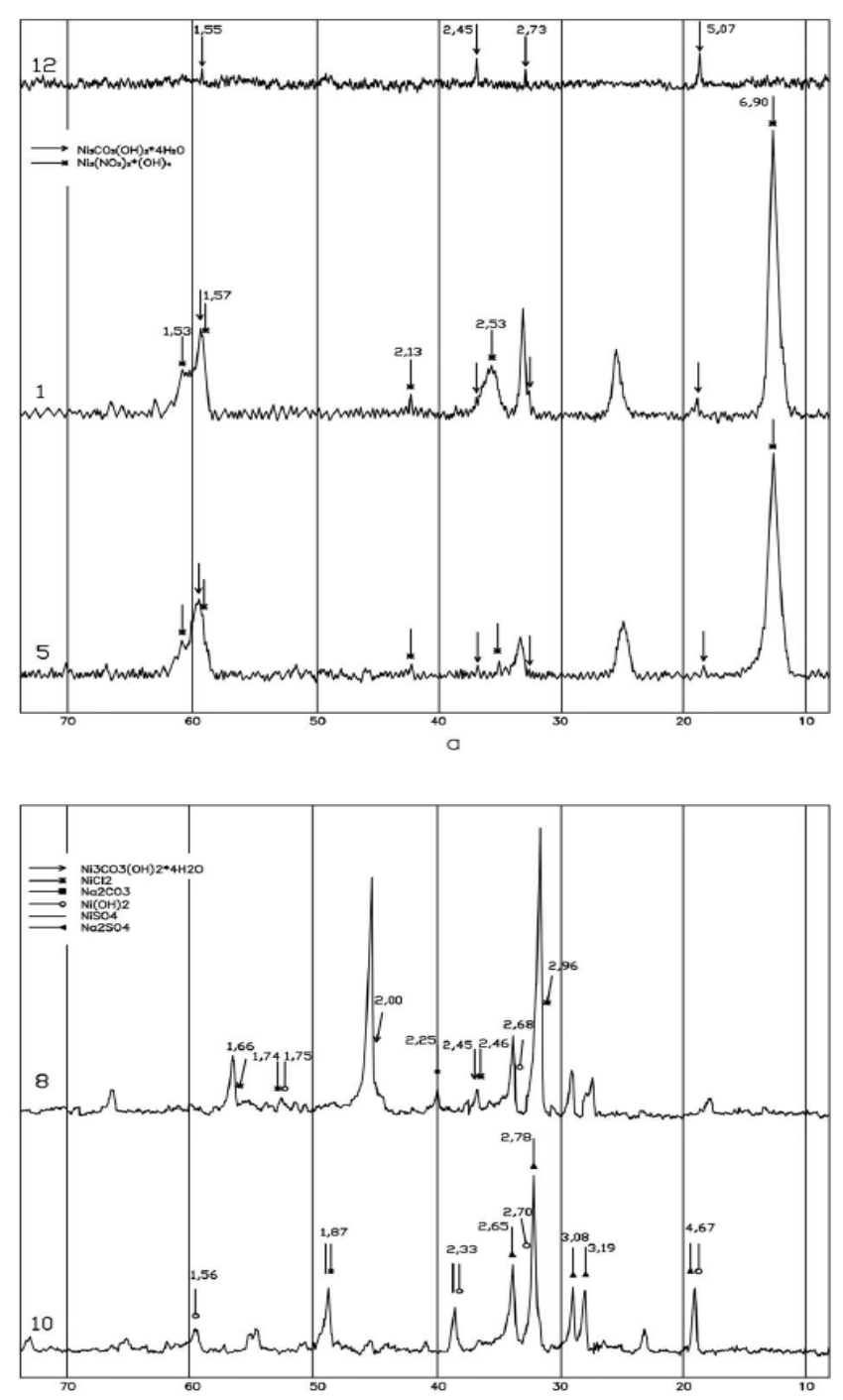

Fig. 1. X-ray powder diffraction patterns of nickel hydroxycarbonate samples

Both basic nickel nitrate $\mathrm{Ni}_{3}\left(\mathrm{NO}_{3}\right)_{2} \cdot(\mathrm{OH})_{4}$ and nickel hydroxycarbonate $\mathrm{Ni}_{2} \mathrm{CO}_{3}(\mathrm{OH})_{2} \cdot 4 \mathrm{H}_{2} \mathrm{O}$ were in the samples $1-7$, obtained from the original nickel nitrate solution. In work [17] the precipitation mechanism of a solution of nickel nitrate by sodium hydroxide has been studied. It has been shown that the precipitation of nickel occurs in stages. The main nitrate is formed initially, then it is transformed into hydroxide. The formation of the 
main nickel nitrate as a result of precipitation by carbamide has been documented in work [3], where the precipitation process has been carried out in an autoclave from aqueous-alcoholic solution of nickel nitrate. Consequently, the main nickel nitrate is quite likely to be the residual intermediate product of precipitation, which did not have time to turn into nickel hydroxide.

A solution of ammonium carbonate salts has a high alkaline reaction. The $\mathrm{pH}$ of the precipitation was supported by adding solution dropwise. Ammonia was added to the solution of ammonium carbonate salts to obtain samples 3 and 4 . However, neither the addition of ammonia nor the precipitation process rate significantly affects the phase composition of precipitators. The presence of identical components in the samples obtained with the use of ammonium carbonate salts (1-4), as well as with urea (5-7) indicates a similar mechanism of precipitants formation. In the process of hydrolysis of urea in a solution, the following reactions (9)-(11) are possible:

$$
\begin{aligned}
& \mathrm{CO}\left(\mathrm{NH}_{2}\right)_{2}+\mathrm{H}_{2} \mathrm{O} \leftrightarrow \mathrm{NH}_{4} \mathrm{COONH}_{2} \\
& \mathrm{NH}_{4} \mathrm{COONH}_{2}+\mathrm{H}_{2} \mathrm{O} \leftrightarrow \mathrm{NH}_{4} \mathrm{HCO}_{3} \\
& 2 \mathrm{NH}_{4} \mathrm{HCO}_{3} \leftrightarrow\left(\mathrm{NH}_{4}\right)_{2} \mathrm{CO}_{3}+\mathrm{H}_{2} \mathrm{CO}_{3}
\end{aligned}
$$

Thus, since ammonium carbonate salts can be considered as products of carbamide hydrolysis, the result of the precipitation process is nickel hydroxycarbonate of a similar chemical composition.
Samples 5-7 have been obtained by homogeneous precipitation of carbamide, which is used to avoid local oversaturation of the solution with the precipitant ion. Due to the gradual hydrolysis of urea by Eq. (2), the same concentration of ammonium ions is created throughout the volume of the solution that, in its turn, leads initially to the precipitation of nickel hydroxide, and then to the formation of nickel carbonate. Taking into consideration that the result of the nickel hydroxide solubility is $3.1 \cdot 10^{-16}$ and that of nickel carbonate is $1.63 \cdot 10^{-7}$, the formation of hydroxide takes place initially, followed by the formation of nickel carbonate.

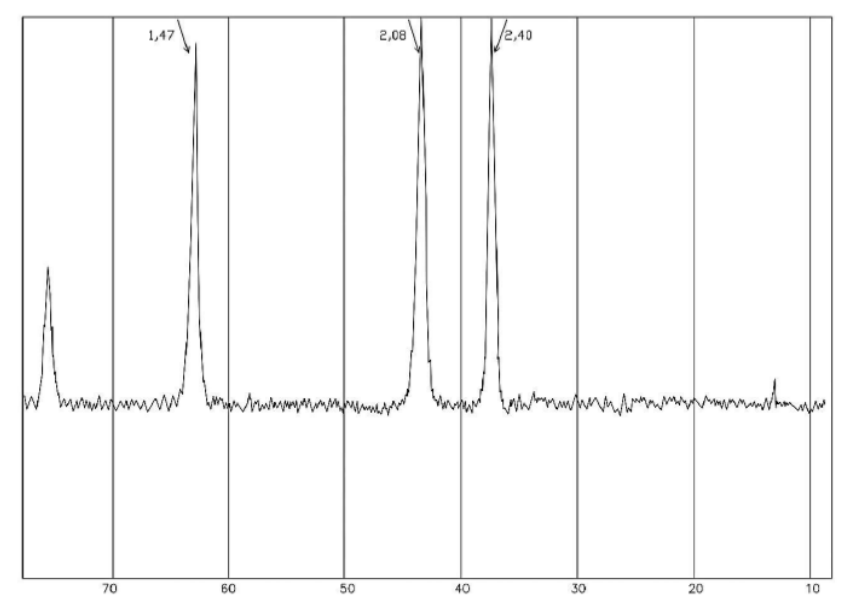

Fig. 2. X-ray powder diffraction patterns of nickel oxide samples

\begin{tabular}{|c|c|c|c|c|c|c|c|c|c|c|}
\hline 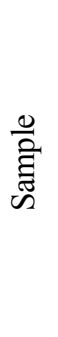 & Initial solution concentration & Precipitant concentration & 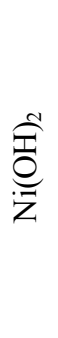 & 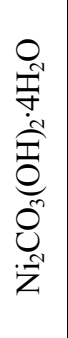 & 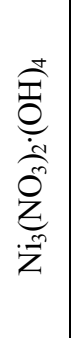 & $\begin{array}{l}O^{+} \\
\text {¿n } \\
\end{array}$ & $\stackrel{\vec{Z}}{\vec{Z}}$ & $\begin{array}{l}\underbrace{}_{\overparen{N}} \\
Z \\
Z\end{array}$ & $\begin{array}{l}O^{+} \\
\mathscr{W}^{\prime} \\
\tilde{Z}^{\prime}\end{array}$ & 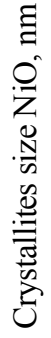 \\
\hline 1 & $\mathrm{Ni}\left(\mathrm{NO}_{3}\right)_{2} ; \mathrm{C}=1.72 \mathrm{~mol} / \mathrm{l}$ & $\left(\mathrm{NH}_{4}\right)_{2} \mathrm{CO}_{3} ; \mathrm{C}=168 \mathrm{~g} / \mathrm{l}$ & & + & + & & & & & 12 \\
\hline 2 & $\mathrm{Ni}\left(\mathrm{NO}_{3}\right)_{2} ; \mathrm{C}=1.72 \mathrm{~mol} / \mathrm{l}$ & $\left(\mathrm{NH}_{4}\right)_{2} \mathrm{CO}_{3} ; \mathrm{C}=168 \mathrm{~g} / \mathrm{l}$ & & + & + & & & & & 12 \\
\hline 3 & $\mathrm{Ni}\left(\mathrm{NO}_{3}\right)_{2} ; \mathrm{C}=1.72 \mathrm{~mol} / \mathrm{l}$ & $\left(\mathrm{NH}_{4}\right)_{2} \mathrm{CO}_{3} ; \mathrm{C}=162 \mathrm{~g} / 1$, ammonia $72 \mathrm{~g} / 1$ & & + & + & & & & & 13 \\
\hline 4 & $\mathrm{Ni}\left(\mathrm{NO}_{3}\right)_{2} ; \mathrm{C}=1.72 \mathrm{~mol} / \mathrm{l}$ & $\left(\mathrm{NH}_{4}\right)_{2} \mathrm{CO}_{3} ; \mathrm{C}=162 \mathrm{~g} / 1$, ammonia $72 \mathrm{~g} / 1$ & & + & + & & & & & 13 \\
\hline 5 & $\mathrm{Ni}\left(\mathrm{NO}_{3}\right)_{2} ; \mathrm{C}=1.80 \mathrm{~mol} / \mathrm{l}$ & Urea & & + & + & & & & & 12 \\
\hline 6 & $\mathrm{Ni}\left(\mathrm{NO}_{3}\right)_{2} ; \mathrm{C}=1.98 \mathrm{~mol} / \mathrm{l}$ & Urea & & + & + & & & & & 12 \\
\hline 7 & $\mathrm{Ni}\left(\mathrm{NO}_{3}\right)_{2} ; \mathrm{C}=0.27 \mathrm{~mol} / 1$ & Urea & & + & + & & & & & 12 \\
\hline 8 & $\mathrm{NiSO} 4 ; \mathrm{C}=1.0 \mathrm{~mol} / \mathrm{l}$ & $\mathrm{Na}_{2} \mathrm{CO}_{3} ; \mathrm{C}=218 \mathrm{~g} / \mathrm{l}$ & + & & & + & & + & & \\
\hline 9 & $\mathrm{NiSO}_{4} ; \mathrm{C}=0.001 \mathrm{~mol} / 1$ & $\mathrm{Na}_{2} \mathrm{CO}_{3} ; \mathrm{C}=218 \mathrm{~g} / \mathrm{l}$ & + & + & & & & + & + & \\
\hline 10 & $\mathrm{NiCl}_{2} ; \mathrm{C}=1.15 \mathrm{~mol} / \mathrm{l}$ & $\mathrm{Na}_{2} \mathrm{CO}_{3} ; \mathrm{C}=218 \mathrm{~g} / \mathrm{l}$ & + & + & & & + & + & & \\
\hline 11 & $\mathrm{NiCl}_{2} ; \mathrm{C}=0.0011 \mathrm{~mol} / 1$ & $\mathrm{Na}_{2} \mathrm{CO}_{3} ; \mathrm{C}=218 \mathrm{~g} / \mathrm{l}$ & & + & & & + & + & & \\
\hline 12 & Nickel hydroxycarbonate & & & + & & & & & & \\
\hline
\end{tabular}

Table 1

Qualitative phase analysis of nickel precipitates 
On X-ray powder diffraction patterns of samples 811, there are diffraction peaks common for nickel hydroxycarbonate $\mathrm{Ni}_{2} \mathrm{CO}_{3}(\mathrm{OH})_{2} \cdot 4 \mathrm{H}_{2} \mathrm{O}$ and precipitates of initial reagents such as nickel sulfate, nickel chloride, and sodium carbonate.

Investigation results [18] show that nickel hydroxide contains anions of salts-precursor solutions.

Samples 1-7 were taken for the purpose of further application to obtain aluminum-nickel catalyst. Therefore, X-ray diffraction line broadening analysis was performed after calcination for $2 \mathrm{~h}$ at the temperature of $773 \mathrm{~K}$ and crystallite sizes of the obtained nickel oxide were defined (Table 1).

It was found out that the crystallites obtained from nickel oxides have a fairly small size. The sizes of nickel oxide obtained from samples 3 and 4 are slightly larger than $13 \mathrm{~nm}$ versus $12 \mathrm{~nm}$, due to the slightly higher content of crystallization water and nickel hydroxide. The rate of the precipitation process has not significantly affected the size of the crystallites.

All samples were analyzed by DTA [16]. Based on the ratio of mass losses corresponding to three temperature intervals, the mole ratio of $x \mathrm{NiCO}_{3} \cdot y \mathrm{Ni}(\mathrm{OH})_{2} \cdot z \mathrm{H}_{2} \mathrm{O}$ has been calculated.

The following calculation algorithm was used:

- calculation of the molar amount of carbonate nickel by weight loss $\Delta m_{3}$ :

$$
n_{\mathrm{NiCO}_{3}}=\frac{\Delta m_{3}}{44}
$$

- molar amount of nickel hydroxide determined by the content of nickel:

$$
n_{\mathrm{Ni}(\mathrm{OH})_{2}}=\frac{C_{\mathrm{Ni}}}{59}-n_{\mathrm{NiCO}_{3}}
$$

- amount of crystallization water:

$$
n_{\mathrm{H}_{2} \mathrm{O}}=\frac{\Delta m_{1}+\Delta m_{2}}{18}-n_{\mathrm{Ni}(\mathrm{OH})_{2}}
$$

Calculations of molar correlations:

$$
x=\frac{n_{\mathrm{NiCO}_{3}}}{n_{\mathrm{NiCO}_{3}}} ; y=\frac{n_{\mathrm{Ni}(\mathrm{OH})_{2}}}{n_{\mathrm{NiCO}_{3}}} ; z=\frac{n_{\mathrm{H}_{2} \mathrm{O}}}{n_{\mathrm{NiCO}_{3}}}
$$

where $\Delta m_{1}, \Delta m_{2}$ and $\Delta m_{3}$ is weight loss at temperature intervals of $323-423 \mathrm{~K}, 423-523 \mathrm{~K}$ and $523-773 \mathrm{~K}$, respectively; 44, 59 and 18 is molar mass of $\mathrm{CO}_{2}, \mathrm{Ni}$ and $\mathrm{H}_{2} \mathrm{O}$, respectively.

The results of studies and calculations are presented in Table 2.

The DTA-graph of sample 12 shows industrial nickel hydroxycarbonate; there is clear endothermic effect of removed water with the maximum at $423 \mathrm{~K}$ and endothermic effect of nickel carbonate decomposition at $593 \mathrm{~K}$. On DTA graph of the samples 1-11 one can observe endothermic effects at 323-533, 543-563 and 583-603 K.

DTA results and following calculations helped to find out that:

i) Precipitates obtained by using non-sodium precipitants (1-7) were similar in chemical composition: nickel hydroxide was $x: y=1:(0.2-0.6)$ and it was significantly different from precipitate obtained by sodium carbonate.

The rate of precipitation affects the yield of the final product. The precipitants obtained in this way, as a rule, have crystals of perfect shape and they are easily laundered from water-soluble impurities.

ii) The amount of crystallization water $(z)$ depends on the process temperature. The precipitates obtained by the precipitation of urea at the temperatures more than $363 \mathrm{~K}$ are characterized by a very small value of $\mathrm{z}=0$ 0.21 , that is explained by the temperature conditions for the formation of precipitates since the removal of a crystallization water began at precipitation temperature

\begin{tabular}{|c|c|c|c|c|c|c|c|}
\hline \multirow[b]{2}{*}{ Sample } & \multicolumn{3}{|c|}{ Mass loss, $\%$} & \multicolumn{3}{|c|}{ Mole ratio } & \multirow[b]{2}{*}{ Ni content, $\%$} \\
\hline & $\begin{array}{c}\Delta m_{1} \\
323-423 \mathrm{~K}\end{array}$ & $\begin{array}{c}\Delta m_{2} \\
423-523 \mathrm{~K}\end{array}$ & $\begin{array}{c}\Delta m_{3} \\
523-773 \mathrm{~K}\end{array}$ & $\begin{array}{c}x \\
\mathrm{NiCO}_{3} \\
\end{array}$ & $\begin{array}{c}y \\
\mathrm{Ni}(\mathrm{OH})_{2}\end{array}$ & $\begin{array}{c}z \\
\mathrm{H}_{2} \mathrm{O} \\
\end{array}$ & \\
\hline 1 & 7.0 & 14.0 & 23.0 & 1 & 0.43 & 1.77 & 44.0 \\
\hline 2 & 8.0 & 12.0 & 26.0 & 1 & 0.2 & 1.8 & 41.8 \\
\hline 3 & 9.0 & 15.0 & 23.0 & 1 & 0.4 & 2.1 & 42.6 \\
\hline 4 & 7.6 & 18.0 & 20.5 & 1 & 0.6 & 2.4 & 42.8 \\
\hline 5 & 3.9 & 0.8 & 27.3 & 1 & 0.46 & 0 & 53.4 \\
\hline 6 & 2.4 & 4.3 & 26.8 & 1 & 0.44 & 0.18 & 51.4 \\
\hline 7 & 2.5 & 8.0 & 30.5 & 1 & 0.43 & 0.21 & 46.0 \\
\hline 8 & 7.0 & 4.0 & 11.0 & 1 & 2.05 & 1.91 & 52.7 \\
\hline 9 & 7.0 & 9.0 & 11.0 & 1 & 2.2 & 1.3 & 47.2 \\
\hline 10 & 13.0 & 5.7 & 12.5 & 1 & 1.7 & 1.8 & 45.6 \\
\hline 11 & 7.0 & 4.0 & 18.0 & 1 & 1.73 & 0.97 & 44.0 \\
\hline 12 & 11.7 & 5.5 & 11.8 & 1 & 2.12 & 1.46 & 49.2 \\
\hline
\end{tabular}
above $323 \mathrm{~K}$.

Table 2

The DTA results for nickel hydroxycarbonate samples 
The precipitates obtained with a mixed solution of carbon ammonium salts and ammonia had higher amount of crystallization water $(z=2.1-2.4)$ than those obtained only with carbon ammonium salts $(z=1.77-1.8)$. The result is a slightly larger size of $\mathrm{NiO}$ crystallites produced from nickel hydroxycarbonate (Table 1).

Due to the fact that the formation of nickel hydroxycarbonate occurs uniformly throughout the volume, which is easily achieved by simple mixing, the formation of a precipitant also occurs throughout the reaction volume. This helps to avoid local oversaturation and heterogeneity of the precipitant. At a sufficiently rapid rate, the carbamide hydrolysis occurs when the solution is heated to the temperature of $363-373 \mathrm{~K}$, as urea itself is of a rather weak base.

iii) Precipitates obtained with sodium carbonate from a solution of nickel sulfate contain much more nickel hydroxide than non-sodium precipitate $x: y=1:(2.05-2.2)$, that was more like to the chemical composition of the precipitates studied in [14] and that was obtained from the same initial materials but at the temperature of $369 \mathrm{~K}$ $(x: y=1.4-2)$. On the X-ray of these samples, nickel hydroxide was also identified (Table 1). The industrial sample had $x: y: z=1: 2.12: 1.46$. The samples obtained from nickel chloride were characterized by slightly less nickel hydroxide amount $x: y=1:(1.7-1.73)$.

The precipitation of nickel hydroxycarbonate by sodium carbonate occurs according to the following mechanism.

Sodium carbonate hydrolyzes in solution by Eq. (16):

$\mathrm{Na}_{2} \mathrm{CO}_{3}+\mathrm{H}_{2} \mathrm{O} \leftrightarrow \mathrm{NaHCO}_{3}+\mathrm{NaOH}$

The formation of sodium hydroxide as a result of hydrolysis reaction (16) promotes the increase of medium $\mathrm{pH}$, which is an additional reason for the intensive formation of nickel hydroxide. The formation of sodium bicarbonate leads to incomplete precipitation of nickel from the solution.
During the precipitation of nickel sodium by carbonate almost insoluble dense nickel hydroxycarbonate precipitate is formed, which is easily separated from the solution. The formation of main salts of variable composition also takes place. The presence of sulfates and sodium in catalysts is undesirable. Therefore, the use of nickel sodium and carbonate sulfate for the production of OKN for catalysts has a significant drawback, which is the need for product washing out.

Since the standards for the manufacture of raw materials for catalysts are very strict regarding the presence of impurities, it was necessary to determine their amount.

The chemical analysis of samples regarding the residuals of initial reagents such as sulfates, nitrates, and chlorides was carried out. The results are shown in Table 3 .

The content of impurities of the initial anions in the test samples is large enough. The content of sulfates and chlorides impurities is also increased. Attention is drawn to the increased content of nitrates in samples 5-7. However, they also contain a small amount of crystallization water and the total content of nickel $\mathrm{NiCO}_{3}+(\mathrm{OH})_{2}$ is larger than in samples 1-4. The conditions of obtaining on the one hand contributed to the increase of the content of the target component, and on the other hand, water could not be sufficient to form nickel hydroxide from the main nickel nitrate.

The presence of nitrates is explained by the presence of basic nickel nitrate in the samples, the formation of which one can observe in other processes of obtaining nickel impurities by means of urea [16]. Samples 8-11 have another structure caused by the peculiarities of the precipitation process with sodium carbonate solution; actually, precipitants obtained under conditions of local solution saturations alongside with a rather high $\mathrm{pH}$ level are hardly filtered or washed from impurities.

Table 4 shows the results of measuring the specific surface area.

Table 3

Chemical analysis of the samples

\begin{tabular}{|c|c|c|c|c|c|c|c|c|c|c|}
\hline \multicolumn{7}{|c|}{$\mathrm{NO}_{3}^{-}$content, $\%$} & \multicolumn{2}{|c|}{$\mathrm{SO}_{4}{ }^{2-}$ content, $\%$} & \multicolumn{2}{|c|}{$\mathrm{Cl}^{-}$content, $\%$} \\
\hline 1 & 2 & 3 & 4 & 5 & 6 & 7 & 8 & 9 & 10 & 11 \\
\hline 3.10 & 3.00 & 1.50 & 1.49 & 4.6 & 4.5 & 4.4 & 1.2 & 2.8 & 1.7 & 0.5 \\
\hline
\end{tabular}

Table 4

Results of specific surface measurement

\begin{tabular}{|c|c|c|c|c|c|}
\hline \multicolumn{7}{|c|}{ Specific surface area, $\mathrm{m}^{2} / \mathrm{g}$} \\
\hline \multicolumn{3}{|c|}{ Active alumina type I } & \multicolumn{3}{c|}{ Active alumina type II } \\
\hline 5 & 6 & 8 & 5 & 6 & 8 \\
\hline 246.9 & 292.9 & 225.7 & 225.0 & 229.1 & 173.8 \\
\hline
\end{tabular}

Sample 8 is obtained from raw materials that are commonly applied for the production of nickel hydroxycarbonates, such as nickel sulfate and sodium carbonate; therefore it is clear that when using active alumina, which is used in the industry, an obtained value of specific surface is similar to the industrial samples $173.8 v \mathrm{~s}$. $170 \mathrm{~m}^{2} / \mathrm{g}$. When using another active alumina, the value of specific surface for this sample is some higher than 
$225.3 \mathrm{~m}^{2} / \mathrm{g}$. The use of homogeneous precipitation usually helps to obtain nanosized metal oxides, ensuring a high specific surface of the catalysts. Obtaining the carrier by the same method confirms this fact. Samples 5 and 6 showed higher value of the specific surface than in common industrial samples in both cases and they have inherent sufficient pore volume compared to the industrial samples.

\section{Conclusions}

Nanosized nickel oxide has been obtained from nickel-free hydroxycarbonate samples. The samples of catalysts made from this nickel oxide showed a specific surface, higher than that of industrial ones. The samples of nickel hydroxycarbonate have been obtained from a solution of nickel nitrate with non-sodium precipitates, i.e. carbamide, and a cheaper semi-product of its production ammonium carbonate salts. Unsaturated nickel hydroxycarbonate has a fairly stable composition, the ratio of the carbonate amount to the hydroxide amount is $x: y=1:(0.2-0.6)$.

The samples are characterized by different content of crystallization water. Its amount is greater in samples that were obtained at low temperatures (293-298 K). Samples obtained at a higher temperature (more than $363 \mathrm{~K}$ ) contain less crystallization water because it is removed at synthesis temperatures. Nickel hydroxide $\mathrm{Ni}(\mathrm{OH})_{2}$ is present in the samples obtained by precipitation of a sodium carbonate solution due to a higher $\mathrm{pH}$ of the solution.

According to the DTA results, it was found that the chemical composition of nickel hydroxycarbonate obtained in this way differs from the samples obtained with sodium carbonate by the ratio of nickel carbonate : nickel hydroxide, which is equal to $x: y=$ $=1:(0.2-0.6)$ in contrast to $x: y=1:(1.7-2.2)$ in the precipitates obtained with sodium carbonate.

In addition to nickel hydroxycarbonate, the samples obtained from nickel sulfate and nickel chloride solutions contain residues of the initial materials - anions of sulfate and chloride.

The precipitates obtained from the solution of nickel nitrate contain a low amount of $\mathrm{Ni}_{3}\left(\mathrm{NO}_{3}\right)_{2} \cdot(\mathrm{OH})_{4}$, the diffraction peaks of which are presented on the X-ray patterns of the samples. The non-sodium precipitates obtained from nickel nitrate contain the basic nitrate, which, when calcined, do not prevent the conversion of the precipitate into highly dispersed nickel oxide $\sim 12-$ $13 \mathrm{~nm}$. Since the basic nitrate is decomposed at the process temperature, its presence does not affect the purity of the obtained oxide and permits the product to be obtained with high dispersion. Catalysts formed from nonsodium precipitates showed a higher value of the specific surface in comparison with the common industrial samples. Such products can be recommended for the production of catalysts.

\section{References}

[1] Lan R., Tao S.: J. Power Sour., 2011, 196, 5021.

https://doi.org/10.1016/j.jpowsour.2011.02.015

[2] Nail B., Fields J., Zhao J. et al.: ACS Nano, 2015, 9, 5135.

https://doi.org/10.1021/acsnano.5b00435

[3] Hu L., Qu B., Chen L., Li Q.: Mater. Lett., 2013, 108, 92. https://doi.org/10.1016/j.matlet.2013.06.060

[4] Aslam S., Subhan F., Yan Z. et al.: Chem. Eng. J., 2017, 315, 469. https://doi.org/10.1016/j.cej.2017.01.047

[5] Zhu G., Xi C., Shen M. et al.: ACS Appl. Mater. Interface., 2014, 6, 17208. https://doi.org/10.1021/am505056d

[6] Koo K., Park M., Jung U. et al.: Int. J. Hydrogen Energ., 2014, 39, 10941. https://doi.org/10.1016/j.ijhydene.2014.05.041

[7] Ribeiro N., Neto R., Moya S. et al.: Int. J. Hydrogen Energ., 2010, 35, 11725. https://doi.org/10.1016/j.ijhydene.2010.08.024 [8] Ertl G., Knözinger H., Weitkamp J.: Handbook of Heterogeneous Catalysis. VCH VerlagsgesellschaftmbH, Weinheim 1997. [9] Cui X., Yuan H., Junge K. et al.: Green Chem., 2017, 19, 305. https://doi.org/10.1039/C6GC01955B

[10] Rhamdhani M., Jak E., Hayes P.: Metallurg. Mater. Transact. B, 2008, 39, 218. https://doi.org/10.1007/s11663-007-9124-4

[11] Guillard D., Lewis A.: Ind. Eng. Chem. Res., 2001, 40, 5564. https://doi.org/10.1021/ie010312q

[12] Taibi M., Ammar S., Jouini N., Fiévet F.: J. Phys. Chem. Solids, 2006, 67, 932. https://doi.org/10.1016/j.jpcs.2006.01.006 [13] Ballesteros F., Salcedo A., Vilando A. et al.: Chemosphere, 2016, 164, 59. https://doi.org/10.1016/j.chemosphere.2016.08.081 [14] Packter A., Uppaladinni S.: Kristall Und Techn., 1975, 10, 985. https://doi.org/10.1002/crat.19750100910

[15] Beskov V., Dobrydnev S., Zamuruev O., Kapaev G.: Izv. Vysshykh Ucheb. Zaved., 2009, 52, 25.

[16] Kong L.-B., Deng L., Li X.-M. et al.: Mater. Res. Bull., 2012, 47, 1641. https://doi.org/10.1016/j.materresbull.2012.03.051

[17] Solovov V., Nykolenko N., Kovalenko V. et al.:Visnyk Nats. Techn. Univ. Khrakiv. Polytech. Inst., 2017, 7, 199.

https://doi.org/10.20998/2413-4295.2017.07.28

[18] Liu C., Li Y.: J. Alloy. Compd., 2009, 478, 415.

https://doi.org/10.1016/j.jallcom.2008.11.049

Received: June 19, 2018 / Revised: September 03, 2018 / Accepted: December 17, 2018

\section{БЕЗНАТРІЙОВИЙ НІКЕЛЬ ГІДРОКСОКАРБОНАТ ДЛЯ НАНОРОЗМІРНИХ КАТАЛІЗАТОРІВ}

Анотація. Отримано та досліджено зразки безнатрійового нікель гідроксикарбонату для нанорозмірних каталізаторів. Розраховано співвідношення кристалічної води, кількості гідроксиду нікелю та карбонату. Рентгенофазовим аналізом отриманого нікель оксиду визначено розмір кристаліту 12-13 нм. Зразки алюмо-нікелевих каталізаторів, одержаних з безнатрійового нікель гідроксикарбонату, забезпечують вищу на $30 \%$ питому поверхню у порівнянні 3 промисловими каталізаторами.

Ключові слова: нікель гідроксікарбонат, осадження, осаджувач, нікель оксид, каталізатори. 